\title{
PEMBERDAYAAN MASYARAKAT DALAM PENCEGAHAN PENYEBARAN VIRUS COVID 19 DI DESA DUYUNG, MOJOKERTO
}

\author{
Tuani Lidiawati Simangunsong ${ }^{1}$, Erna Andajani ${ }^{2}$, Arum Soesanti ${ }^{3}$, Wafia Silvi Dhesinta Rini ${ }^{4}$ \\ ${ }^{1}$ Jurusan Teknik Kimia - Pusat Studi Lingkungan dan Energi Terbarukan, Universitas Surabaya \\ ${ }^{2}$ Jurusan Manajemen, Universitas Surabaya \\ ${ }^{3}$ Jurusan Teknik Mesin dan Manufaktur, Universitas Surabaya \\ ${ }^{4}$ Fakultas Hukum, Universitas Surabaya \\ tuani@staff.ubaya.ac.id,ernajani@staff.ubaya.ac.id,arum_soesanti@staff.ubaya.ac.id, \\ wafiasdhesinta@staff.ubaya.ac.id
}

\begin{abstract}
Abstrak
Masuknya virus Covid 19 ke Indonesia pertengahan Maret 2020 lalu membuat masyarakat harus mewaspadai penyebaran virus ini ke daerahnya. Program Pemberdayaan Masyarakat Desa (PPDM) merupakan hibah dari Kemenristekbrin yang dilakukan Universitas Surabaya di desa Duyung, mencermati bahwa pencegahan penyebaran virus Covid 19 ke desa ini menjadi satu hal yang penting dilakukan sehingga menjadikan isu ini menjadi salah satu program dalam pengabdian yang dilakukan di desa tersebut. Tujuan dari pemberdayaan adalah untuk mencegah penyebaran virus Covid 19. Metode yang dilakukan adalah 1. Sosialisasi kepada para perangkat dan masyarakat desa Duyung, 2. Pembentukan Relawan Desa Lawan Covid 19, 3. Edukasi Masyarakat melalui spanduk yang dipasang di beberapa jalan yang banyak dilewati warga, dan 4. Penyemprotan secara berkala dan pembentukan posko Covid 19. Selain itu, pihak Desa Duyung juga melarang kunjungan warga dari luar selama bulan Maret-Juni dan membatasi akses warga dari luar desa untuk berkunjung ke desa tersebut setelah bulan Juni. Hasil kegiatan menunjukkan bahwa sampai saat ini belum ada warga yang terjangkit Covid 19 dan Desa Duyung mendapat apresiasi dari bupati Mojokerto karena merupakan Kampung Tangguh Covid 19.
\end{abstract}

Kata Kunci : Covid 19, desa Duyung, pemberdayaan

PENDAHULUAN

Desa Duyung merupakan salah satu desa Kecamatan Trawas, Mojokerto yang sedang dikembangkan menjadi desa wisata. Berdasarkan RJPMD Desa Duyung, 2014-2019 akan ada 6 (enam) destinasi wisata yang akan dikembangkan. Keenam destinasi wisata tersebut adalah peninggalan sejarah (situs) Sawah Lumpang, situs Watu Dakon, air terjun Sumber Lumpang, Bukit Emas, Gua Watu Kelir, dan Tebing Watu Gedhek. Universitas Surabaya (Ubaya) melalui Program Pengembangan Desa Mitra (PPDM) dari Kemenristek-Brin bekerjasama dengan desa Duyung untuk mewujudkan desa wisata berbasis lingkungan. Fokus dari program ini adalah pengembangan destinasi wisata dan penguatan lembaga pengelola desa wisata.

Masuknya virus Covid 19 ke Indonesia pertengahan Maret 2020 menyebabkan desa harus menutup kunjungan wisatawan ke destinasi wisatanya sebagai langkah awal pencegahan penyebaran virus ini. Ubaya mencermati bahwa Lingkungan Hidup dan Kebencanaan 
pencegahan penyebaran virus Covid 19 ke desa ini menjadi satu hal yang penting dilakukan sehingga menjadikan isu ini menjadi salah satu program dalam pengabdian yang dilakukan di desa tersebut. Ubaya menyadari perlu ada sinergi antara warga, pihak desa, dan perguruan tinggi agar penyebaran virus Covid 19 bisa dikendalikan dengan baik. Artinya pemberdayaan masyarakat merupakan kunci penting dalam pencegahan penyebaran virus ini. Tujuan dari pemberdayaan masyarakat adalah mencegah penyebaran virus Covid 19.

Pemerintah pusat dan daerah sendiri telah mengeluarkan kebijakan-kebijakan terkait pencegahan penyebaran virus Covid 19, diantaranya: PP No. 21 Tahun 2020 tentang PSBB, Permenkes No. 9 Tahun 2020 tentang PSBB, Maklumat Kapolri Nomor Mak/2/11l/2020 tentang Kepatuhan Terhadap Kebijakan Pemerintah dalam Penanganan Penyebaran Virus Corona, dan PerGub Jatim No. 21 tahun 2020 tentang Perubahan Atas PerGub No. 18 Tahun 2020 tentang Pedoman PSBB dalam Penanganan Covid 19 di Provinsi Jatim. Peraturanperaturan tersebut dijadikan acuan pihak kabupaten Mojokerto untuk memberikan arahan terkait penanganan pandemi Covid 19 kepada desa-desa yang ada di kabupaten Mojokerto termasuk desa Duyung. Pihak desa Duyung sendiri segera mengambil langkah cepat dengan mengeluarkan SK no. 33 tahun 2020 tentang Pembentukan Relawan Desa Lawan Covid 19 pada bulan April 2020 setelah sebelumnya dilakukan sosialisasi oleh Ubaya.

Tujuan pembentukan relawan adalah untuk mengajak masyarakat terlibat aktif dalam pencegahan penyebaran Covid 19. Pihak Ubaya tetap melakukan pendampingan terkait penyebaran virus Covid 19 di desa Duyung dimana tim secara kontinyu berkoordinasi dengan pihak desa melalui kepala desa dan kepala dusun untuk memantau perkembangan virus Covid di desa Duyung. Koordinasi yang sering dilakukan terkait penyemprotan desinfektan dan kebutuhan sarana dan prasarana untuk pencegahan penyebaran virus Covid 19. Koordinasi dilakukan seminggu sekali secara online karena tidak memungkinkan untuk dilakukan kunjungan ke desa selama diberlakukannya PSBB. Koordinasi secara online ini juga dibarengi pembuatan video dan foto oleh pihak desa agar tim
Ubaya tetap bisa melihat proses kegiatan yang telah dilakukan.

\section{METODE}

Metode yang dilakukan dalam program pencegahan penyebaran virus Covid 19 antara lain: 1. Sosialisasi kepada para perangkat dan masyarakat desa Duyung, 2. Pembentukan Relawan Desa Lawan Covid 19, 3. Edukasi Masyarakat melalui spanduk yang dipasang di beberapa jalan yang banyak dilewati warga, dan 4. Penyemprotan secara berkala serta pembentukan posko Covid 19.

\section{Sosialisasi Kepada Perangkat dan Masyarakat Desa duyung}

Langkah awal dari pelaksanaan program adalah sosialisasi kepada perangkat desa dan masyarakat. Dalam sosialisasi ini disampaikan tingkat bahaya virus Covid 19, pentingnya mematuhi protokol kesehatan, perlunya peraturan atau kebijakan dari pihak desa terkait virus Covid 19, pentingnya keterlibatan masyarakat, dan dukungan yang bisa diberikan oleh pihak Ubaya kepada desa. Covid-19 merupakan penyakit menular yang berpotensi menimbulkan kedaruratan kesehatan masyarakat. Oleh sebab itu, tindakan pencegahan terhadap jenis penyakit menular tersebut wajib dilakukan secepat mungkin. Indonesia sebagai negara hukum, maka pencegahan terhadap jenis penyakit menular tersebut wajib dibentuk dalam sebuah aturan atau regulasi (Telaumbanua, 2020).

\section{Pembentukan Relawan Desa Lawan Covid 19}

Pembentukan relawan didukung dengan dibuatnya SK no. 33 tahun 2020 tentang Pembentukan Relawan Desa Lawan Covid 19 oleh kepala desa Duyung. Relawan diberi tugas dan tanggung jawab untuk melakukan penyemprotan desinfektan tiga kali seminggu dan mencegah masuknya kendaraan dari luar desa Duyung mulai hari Jumat - Minggu. Hal ini dilakukan karena masih ada warga di luar desa yang masuk ke desa untuk

Lingkungan Hidup dan Kebencanaan

480 
melakukan perdagangan dengan warga Duyung. Pihak desa juga melarang mudik bagi warga Duyung yang tinggal di luar kota dan tidak mengijinkan warga yang mudik masuk ke desa Duyung.

\section{Edukasi pada Masyarakat Melalui Spanduk}

Dalam sosialisasi yang dilakukan oleh Ubaya juga disinggung terkait pentingnya mengedukasi masyarakat terkait virus covid 19. Hal ini sejalan dengan kebijakan pihak kabupaten agar setiap desa membuat spanduk yang berhubungan dengan Covid 19. Ubaya dan pihak desa berkolaborasi dalam menyediakan spanduk yang dipasang di beberapa ruas jalan yang banyak dilewati warga, yaitu: jalan masuk dusun, balai desa, dan jalan menuju destinasi wisata.

\section{Penyemprotan Secara Berkala dan Pembentukan Posko Covid 19}

Kegiatan penyemprotan desinfektan yang dilakukan oleh relawan tiga kali seminggu mulai April-Juni dan dua kali seminggu mulai JuliSeptember. Kegiatan ini penting dilakukan untuk mencegah penyebaran virus Covid 19. Penyemprotan dilakukan pada jalan desa, rumah penduduk, tempat ibadah, balai dusun, dan balai desa serta area tertentu yang dianggap perlu. Penjadwalan dan pembagian tim relawan dilakukan agar seluruh desa bisa terlayani dengan baik. Dalam setiap penyemprotan didampingi oleh perangkat desa serta dilakukan himbauan kepada warga agar selalu mematuhi protokol kesehatan.

\section{HASIL DAN PEMBAHASAN}

Penyebaran virus Covid 19 di Indonesia mewajibkan setiap pemerintah daerah termasuk pemerintah tingkat desa melakukan tindakan pencegahan agar virus ini tidak terjangkit pada warga di wilayah tersebut. Pemerintah desa Duyung juga melakukan hal yang sama dengan cara melibatkan masyarakat melalui pembentukan relawan Covid 19, mengedukasi masyarakat, dan membuat posko Covid 19.

\section{Peran Serta Masyarakat}

Peran serta masyarakat terlihat pada pembentukan Relawan Desa Cegah Covid 19. Relawan yang sebagian besar adalah anak muda bersedia menyediakan waktu dan tenaga bersamasama dengan masyarakat mencegah penyebaran virus ke desa Duyung. Masyarakat desa juga aktif berperan serta dengan mendukung kegiatan relawan ini. Warga secara bergantian menyediakan makanan bagi relawan yang melakukan penyemprotan maupun yang bertugas menjaga desa di malam hari. Gambar 1. adalah sebagian dari relawan cegah Covid 19.

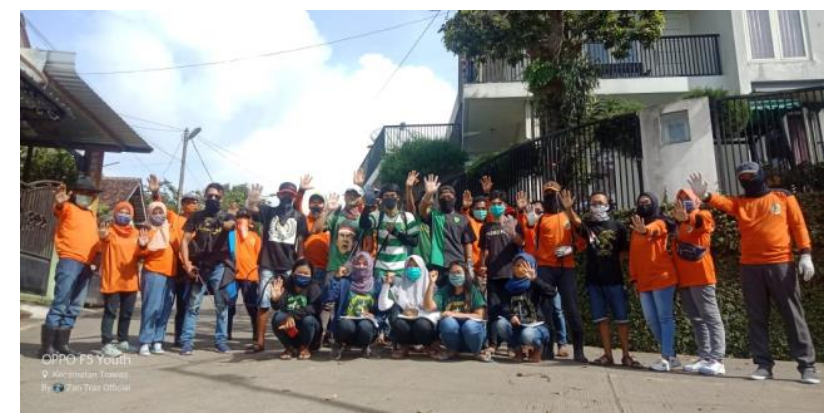

Gambar 1. Relawan Covid-19 Desa Duyung

Sebagai dukungan kepada pihak desa, Ubaya menyediakan sarana dan prasarana yang dibutuhkan bagi kegiatan pencegahan penyebaran virus Covid 19 dengan memberikan masker, electric sprayer, desinfentan, sabun cuci tangan, dan bak cuci tangan. Gambar 2. Memperlihatkan sebagian dukungan yang diberikan Ubaya kepada pihak desa.

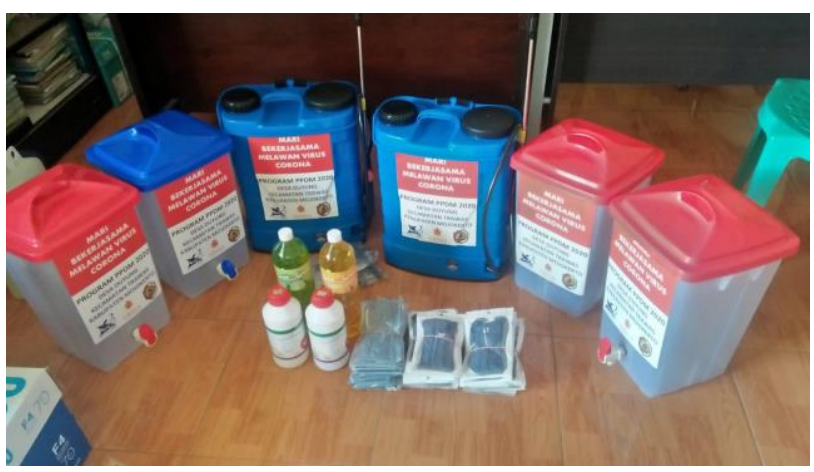

Gambar 2. Masker, Elektric Sprayer, Desinfektan, dan Bak Cuci Tangan Bagi Desa 
Syafrida dan Hartati, 2020 menyatakan bahwa peran serta masyarakat atau keterlibatan masyarakat sangat dibutuhkan sebagai upaya untuk melawan covid 19, memutuskan mata rantai penyebaran virus Corona dengan melakukan social distancing (menjaga jarak), lockdown, karantina wilayah, tetap menjaga kesehatan dan kebersihan lingkungan, penyediaan Alat Pelindung Diri (APD). Hal yang paling sederhana dan paling efektif menekan dan memutus mata rantai penyebaran Covid -19 adalah untuk tidak keluar untuk tetap di rumah saja, dan menjaga jarak, jika berada di tempat umum atau keramaian, menggunakan masker serta sering untuk mencuci tangan dan cukup istirahat agar kekebalan tubuh tetap terjaga dengan baik. Upaya memutus mata rantai penyebaran Covid-19 merupakan tanggung jawab bersama pemerintah, masyarakat, pihak swasta, lembaga keagamaan, tokoh agama, aparat penegak hukum, media sosial dan media elektronik.

\section{Edukasi Pada Masyarakat}

Masyarakat tidak akan bisa mengaplikasikan protokol kesehatan jika tidak dibarengi dengan edukasi atau pengetahuan yang memadai. Edukasi yang dilakukan pada masyarakat Duyung melalui spanduk maupun himbauan terkait dengan apa itu virus Covid 19, bagaimana penularannya, apa gejala orang yang terjangkit virus ini, bagaimana pencegahan penularan virus ini, protokol kesehatan yang harus dipatuhi, PSBB, dan lockdown. Berikut adalah spanduk PSBB yang dipasang pada jalan masuk desa.

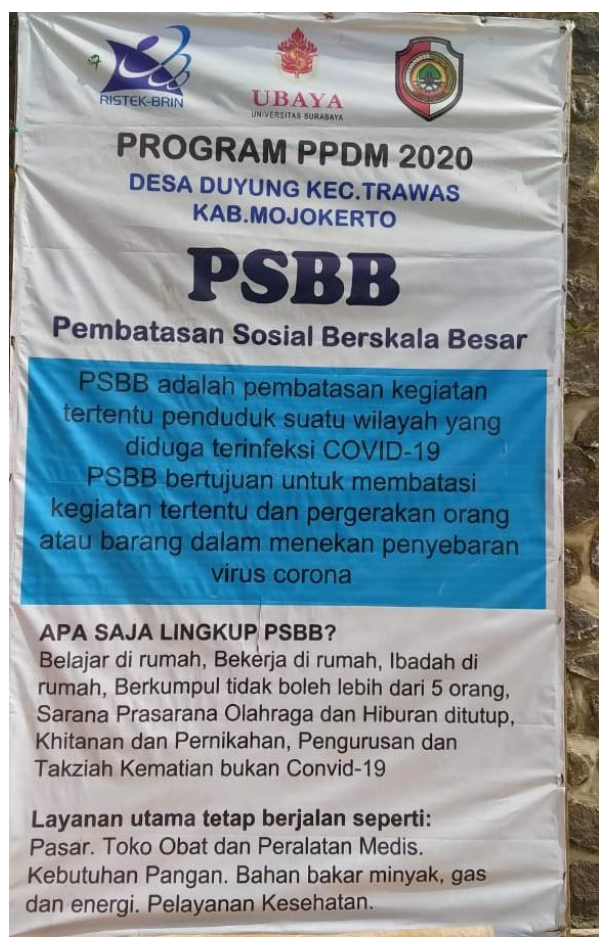

Gambar 3. Spanduk PSBB

Pengetahuan tentang proses penularan virus dan pencegahan yang bisa dilakukan penting untuk mengubah perilaku masyarakat karena tindakan yang nyata tidak akan pernah dilakukan jika masyarakat tidak mempunyai pengetahuan (Utami, dkk, 2020). Pengetahuan masyarakat dalam mencegah transmisi penyakit akan menekan penularan COVID-19 lebih lanjut (Law, Leung, \& Xu, 2020). Gambar di bawah merupakan spanduk yang berisi tentang protokol kesehatan.

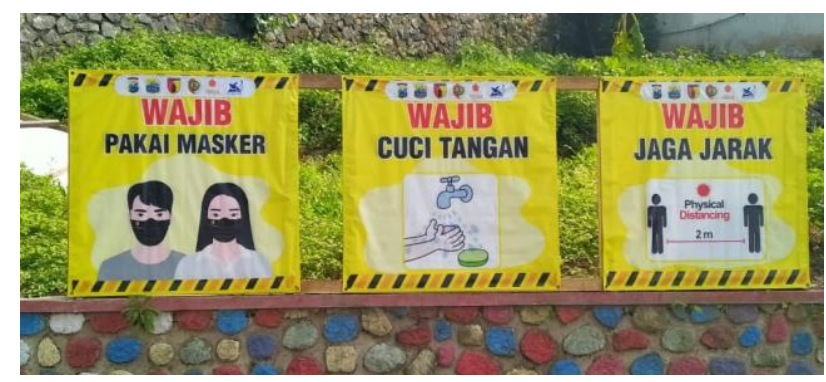

Gambar 4. Spanduk Protokol Kesehatan Sebagai Media Edukasi

Dalam kasus Covid 19 dimana belum ada pengobatan yang disepakati, sangat penting untuk mencegah penyebarannya dalam komunitas. Hal-hal utama yang bisa dilakukan dalam pencegahan Lingkungan Hidup dan Kebencanaan 
penyebaran dalam komunitas antara lain: kebersihan tangan, jaga jarak, dan karantina/isolasi (Güner, et., al, 2020). Lee, 2020 menyarankan agar masyarakat mengikuti petunjuk proteksi terhadap virus Covid 19 yang dikeluarkan oleh WHO atau lembaga terkait hal tersebut. Spanduk merupakan salah sarana yang bisa digunakan untuk memberikan pengetahuan kepada masyarakat atau komunitas tentang pencegahan penyebaran virus ini.

Penelitian yang dilakukan oleh Yanti, dkk, 2020 menyatakan bahwa ada korelasi antara pengetahuan dan perilaku masyarakat. Pengetahuan yang baik akan membuat masyarakat memiliki sikap positif dan perilaku yang baik terkait social distancing, yang merupakan salah satu dari protokol kesehatan yang harus dipatuhi masyarakat. Intervensi dan kampanye ditujukan untuk mempengaruhi perilaku seseorang. Intervensi didasarkan pada teori yang meningkatkan pengetahuan masyarakat dan kesadaran akan risiko kesehatan tertentu akan menghasilkan perubahan perilaku yang positif (Andrews et al., 2020).

\section{Pembentukan Posko Covid 19}

Posko yang dimaksud adalah posko yang berada di balai desa yang difungsikan sebagai ruang isolasi bagi pasien yang terjangkit Covid 19 dan posko berupa tenda yang berada di jalan masuk desa yang berfungsi mencegah warga di luar desa masuk ke desa Duyung. Sejauh ini belum ada warga yang terjangkit virus Covid 19 sehingga posko yang berada di balai desa belum difungsikan. Berikut merupakan gambar posko yang berada di balai desa Duyung.

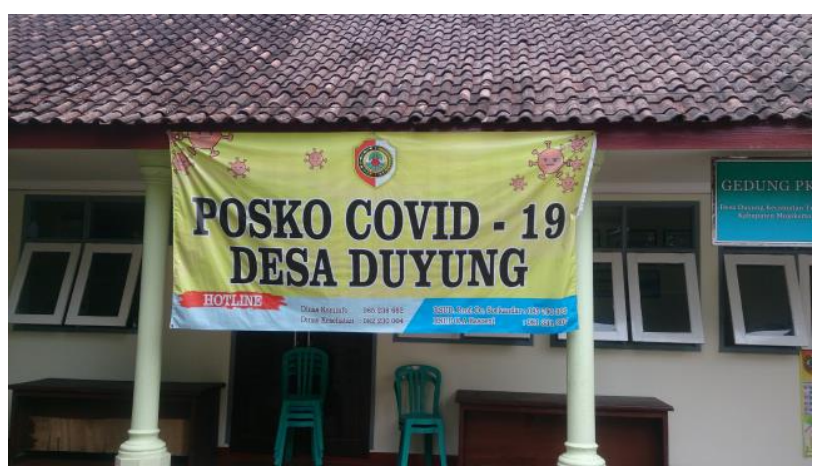

Gambar. 5 Posko Covid 19 Desa Duyung
Posko selanjutnya adalah posko yang berada di jalan masuk desa. Posko ini dipakai oleh pihak Desa Duyung juga melarang kunjungan warga dari luar selama bulan Maret-Juni dan membatasi akses warga dari luar desa untuk berkunjung ke desa tersebut setelah bulan Juni. Selama Maret-Juni pihak desa melakukan pembatasan kepada warga untuk melakukan kegiatan di luar rumah. Kebijakan lockdown ini dilakukan karena masih ditemukan warga luar desa yang berkunjung ke desa Duyung. Pada posko ini juga dilakukan pengukuran suhu tubuh pada warga yang akan masuk desa Duyung.

Lockdown dapat membantu mencegah penyebaran virus Corona ke suatu wilayah sehingga masyarakat yang berada di wilayah tersebut diharapkan dapat terhindar dari wabah yang sedang menyebar. Dampak positif dari kebijakan lockdown adalah pemerintah dapat mengurangi jumlah masyarakat yang terdampak virus Covid-19, karena mengurangi aktifitas diluar dapat menjaga resiko penularan yang tinggi (Yunus dan Rezki,2020). Selan itu penelitian yang dilakukan oleh Yunus dan Rezki, 2020 juga menunjukkan bahwa kegiatan lockdown dalam suatu wilayah yang terdampak wabah virus corona perlu dilakukan sebagai upaya meminimalisir penyebaran virus tersebut. Dengan demikian kebijakan lockdown akan menguntungkan baik pada dareah yang belum terdampak Covid 19 maupun pada daerah yang terdampak Covid 19. Gambar 6. memperlihatkan posko yang terletak di jalan masuk desa.

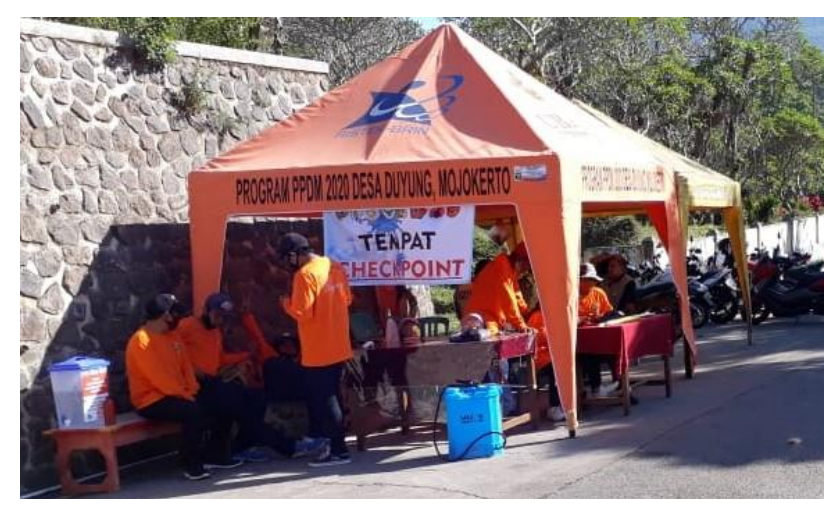

Gambar 6. Tenda Posko pada Jalan Masuk Desa

Sejauh ini belum ada satu warga desa Duyung yang terjangkit virus Covid 19. Hal ini mendapat apresiasi dari kabupaten Mojokerto dimana desa Duyung menjadi salah satu desa yang mendapat kunjungan dari Bupati Mojokerto.

Lingkungan Hidup dan Kebencanaan 
Kunjungan ini terkait keberhasilan desa Duyung dalam mencegah penyebaran virus Covid 19. Berita terkait kunjungan Bupati Mojokerto ada pada link berikut https://jejakkasus.info/tiga-desa-kampungtangguh-kecamatan-trawas-dikunjungi-bupatimojokerto-h-pungkasiadi-sh/. Kondisi ini perlu dijaga dan dipertahankan sehingga pihak desa dan masyarakat mempunyai pekerjaan berat untuk menjaga konsistensi dalam mempertahankan kondisi desa tetap bebas Covid 19.

Dahab, et., al, 2020 menyarankan untuk melakukan pembatasan pergerakan pada masyarakat sebagai langkah utama mengembangkan strategi mitigasi yang sesuai dan berkelanjutan untuk mencegah transmisi dari virus Covid 19.

Jika pada waktu mendatang akan diterapkan new nomal maka Utami, dkk, 2020 memberikan saran bahwa penerapan new normal harus diimbangi dengan kepatuhan yang tinggi dari masyarakat akan pencegahan COVID-19 agar tidak bertambah kasus baru. Proses Adaptasi Kebiasaan Baru (AKB) harus konsisten dilaksanakan mulai dari penggunaan masker, menjaga jarak, mencuci tangan, tidak melakukan kontak fisik, meningkatkan daya tahan tubuh melalui asupan nutrisi dan olahraga.

\section{KESIMPULAN}

Keberhasilan desa Duyung dalam mencegah penyebaran virus Covid 19 adalah pada pemberdayaan masyarakat yang dilakukan dengan maksimal. Keberhasilan tersebut terkait dengan 1) Dukungan pembentukan relawan Covid 19 di desa Duyung dengan membantu penyediaaan sarana dan prasarana pendukung, 2)Edukasi melalui banner yang dipasang di jalan masuk desa 3) Posko tenda untuk mencegah masuknya orang luar ke desa Duyung.

\section{UCAPAN TERIMAKASIH}

Kemristek/BRIN yang telah mendanai Program Pengabdian pada Masyarakat dengan judul PPDM Desa wisata Berbasis Lingkungan di Desa Duyung, Kecamatan Trawas, Mojokerto melalui Dana DIPA Deputi Bidang Penguatan Riset dan Pengembangan Kemenristek/BRIN sesuai dengan Kontrak Pelaksanaan Program Pengabdian Kepada Masyarakat Nomor:105/SP2H/PPM/DRPM/2020, tanggal 16 Maret 2020

\section{REFERENSI}

Andrews, J. L., Foulkes, L., \& Blakemore, S. J. (2020). Peer Influence in Adolescence: PublicHealth Implications for COVID-19. Trends in Cognitive Sciences, 24(8), 585-587. https://doi.org/10.1016/j.tics.2020.05.001

Dahab, M., van Zandvoort, K., Flasche, S., Warsame, A., Ratnayake, R., Favas, C., Spiegel,P. B., Ronald J. Waldman, R.J., \& Checchi, F. (2020). COVID-19 Control in Low-income Settings and Displaced Populations: What can Realistically be Done?. Conflict and Health, 14(14): 1-6. https://doi.org/10.1186/s13031-020-00296-8

Güner, R., Hasanoḡlu, I., \& Aktaș, P., (2020). COVID-19: Prevention and Control Measures in Community. Turkish Journal of Medical Sciences. 50: 571-577. doi:10.3906/sag-2004-146

Law, S., Leung, A. W., \& Xu, C. (2020). Severe Acute Respiratory Syndrome (SARS) and Corona Virus Disease-2019 (COVID-19): From Causes to Preventions in Hong Kong. International Journal of Infectious Diseases, 94, 156-163. https://doi.org/10.1016/j.ijid.2020.03.059

Lee, Jingyi. (2020). 2019 Novel Coronavirus (COVID-19): A Review. IDOSR Journal of Science and Technology, 5(1): 29-36

Syafrida, Hartati. R., (2020). Bersama Melawan Virus Covid 19 di Indonesia. SALAM, 7(6): 495-508. DOI: $10.15408 /$ sjsbs.v7i6.15325

Telaumbanua, Dalinama. (2020). Urgensi Pembentukan Aturan Terkait Pencegahan Covid-19 di Indonesia. Qalamuna - Jurnal Pendidikan, Sosial, dan Agama, 12(1): 59-70.

Utami, R.A., Mose. R.E., \& Martini. (2020). Pengetahuan, Sikap, dan Keterampilan Masyarakat dalam Pencegahan Covid-19 di Provinsi DKI Jakarta. Jurnal Kesehatan Holistic, 4(2): 68-77. DOI: $10.33377 / j k h . v 4 i 2.85$

Yanti, B., Mulyadi,E., Wahiduddin, Novika, R. G. H., Arina, Y. M. D., Martani, N.S., \& Nawan. (2020). Pengetahuan, Sikap, dan Perilaku Masyarakat terhadap Kebijakan Jaga Jarak sebagai Cara Pencegahan Penularan COVID-19 di Indonesia. Jurnal Administrasi Kesehatan Indonesia. 8(1): 414. Doi: 10.20473/jaki.v8i2.2020.4-14

Lingkungan Hidup dan Kebencanaan 484 
Yunus, N.R., \& Rezki, A. (2020). Kebijakan Pemberlakuan Lock Down Sebagai Antisipasi
Penyebaran Corona Virus Covid-19. SALAM, 7(3):

227-238. DOI: 10.15408/sjsbs.v7i3.15083 